\title{
МОДЕЛЮВАННЯ ГОСТРОЇ АСПІРАЦІЙНОЇ БРОНХОПНЕВМОНІЇ
}

\author{
Пенський Павло ${ }^{1}$, Литвинець Михайло르, Мусієнко Дар'я ${ }^{1}$, Зябліцев Сергій ${ }^{3}$ \\ ${ }^{1}$ Студент медичного факультету № 4 НМУ імені О.О. Богомольця, м. Київ, Україна \\ ${ }^{2}$ Студент медичного факультету № 2 НМУ імені О.О. Богомольця, м. Київ, Україна \\ ${ }^{3}$ Кафедра патофізіології НМУ імені О.О. Богомольця, м. Київ, Україна
}

Анотація. На даний час існує нагальна потреба у створенні доступної експериментальної моделі для відтворення основних патогенетичних механізмів COVID-асоційованого ушкодження легень. Першим етапом такої моделі може бути відтворення гострої аспіраційної бронхопневмонії у щурів. Мета - створення ефективної та біологічно безпечної моделі гострої аспіраційної бронхопневмонії. Методи. Групі лабораторних щурів лінії Вістар (n=20) 3 повним дотриманням біоетичних норм під тіопенталовим знеболюванням було проведене оперативне втручання з введенням у трахею стерильної капронової нитки довжиною 2,5 см та товщиною 0,2 мм на глибину 2,5 см. У контрольну групу увійшло 5 тварин. На 7 i 21 добу тварин виводили з експерименту, робили патоморфологічні, изитологічні та гематологічні дослідження. Для статистичних досліджень використано програму MedStat (США). Результати. Протягом спостереження у тварин наростали явища цуіанозу шкірних покривів та слизових оболонок, дихання утруднювалося з активним залученням дихальних м'язів, вислуховувалися виражені хрипи, крепітація. Ректальна температура збільшувалася на 1-1,5 C. На 21-й день збільшувався гранулоцитарно-лімфоциитарний індекс (y 1,5 рази; $p=0,003)$. На секційному дослідженні через 7 діб легені були набряклими, блідо-рожевого кольору, мали нашарування фібрину, виражений ціаноз, внутрішньотканинні геморагії. Через 21 добу иі зміни доповнювалися розвитком ателектазу та фіброзу. Цитологічне дослідження показало проліферацію фіброзної тканини з активацію біосинтетичних процесів, виражену дистрофію бронхіального епітелію, лімфоїдн інфільтрацію. Висновок. Модель гострої аспіраційної бронхопневмонії у шурів дозволяє отримати основні клінічні та морфологічні прояви гострого пошкодження легень з наявністю иіанозу, задишки, вологих хрипів та крепітації, а у легенях - набряку, крововиливів, активного фіброзування.

Ключові слова: аспіраційна гостра бронхопневмонія, експеримент, гострий респіраторний дистрес-синдром, фіброз.

Вступ. На сьогоднішній день коронавірусне захворювання 2019 року (COVID-19) є чумою XXI століття, яка є серйозною загрозою стану громадського здоров'я (Qu, Li, \& Ren, 2020; World Health Organization, 2020). Почавшись у грудні 2019 року в китайському місті Ухань, COVID-19 швидко охопив увесь світ. За даними університету Джона Хопкінса станом на «02» лютого 2021 року у світі було зареєстровано 103684249 випадків захворювання, загинуло 2246844 особи ("COVID-19. Dashboard by the Center”, 2021). Збудником захворювання $є$ ко- ронавірус 2 (Severe Acute Respiratory Syndrome Coronavirus 2 - SARS-CoV-2) (Lu et al., 2020). Вірус ушкоджує різні органи, але найбільшого ураження зазнають легені (Huang et al., 2020).

На ранній ексудативній стадії легеневого пошкодження спостерігається дифузне пошкодження альвеол із руйнуванням епітеліальних та ендотеліальних клітин (Suster \& Moran, 2013). В подальшому розвивається друга - проліферативна стадія 3 виходом у легеневий фіброз. Особливістю SARS-acoційованого ушкодження легень $є$ наявність в 
інтерстиції великої кількості розсіяних мононуклеарних клітин, внутрішньоальвеолярних крововиливів, гнійного запалення та організованої пневмонії (Franks et al., 2003).

Основною причиною летальності від COVID-19 є розвиток альвеолярно-інтерстиціального набряку легень по типу гострого респіраторного дистрес-синдрому (ГРДС) на тлі імунної гіперреактивності та системної запальної реакції (Franks et al., 2003). Зафіксована частота ГРДС при COVID-19 становить 15,6-31\%, що перевищує частоту пошкоджень інших органів (Huang et al., 2020). Найчастішими симптомами є гарячка $(87,9 \%)$, сухий кашель $(67,7 \%)$, втома $(38,1 \%)$, відходження мокроти $(33,4 \%)$, утруднення дихання $(18,6 \%)$, біль у м'язах або суглобах $(14,8 \%)$, біль у горлі $(13,9 \%)$, головний біль $(13,6 \%)$ та озноб (11,4\%). Найпоширенішим респіраторним симптомом COVID-19 є сухий кашель (59,4-82\%) (Wang et al., 2020). Комп'ютерна томографія грудної клітини зазвичай показує мультифокальні двосторонні плямисті тіні та/або матове помутніння у легенях, у деяких випадках спостерігалася змішана картина помутніння і консолідації «матового скла» (Chung et al., 2020).

Патофізіологія ГРДС при COVID-19 включає порушення регуляції легеневої перфузії 3 «цитокіновим штормом», який викликає підвищену проникність судин і обумовлює тяжкий перебіг захворювання (Cai et al., 2020). Багато питань щодо механізмів розвитку легеневого пошкодження лишаються нез'ясованими, що потребує активного підключення тваринних моделей з відтворенням основних ланок патогенезу захворювання.

Лабораторні гризуни несприйнятливі до інфекції SARS-CoV-2 через низьку афінність зв'язування вірусу з білком ангіотензинперетворюючого ферменту 2 (ACE2), тоді як виведення трансгенних порід 3 високою чутливість до ACE2 у широких дослідженнях є обмеженим (Golden et al., 2020). Крім того, проведення дослідів 3 живим збудником цієї хвороби у зв'язку з біологічною небезпечністю на даний час не $є$ широко доступним. Використання адаптованого до гризунів вірусу SARS-CoV-2 також обмежена (Boudewijns et al., 2020; Leist et al., 2020).

Отже, існує потреба у створенні доступної експериментальної моделі для відтворення основних патогенетичних механізмів COVID-асоційованого ушкодження легень. Першим етапом такої моделі може бути відтворення гострої аспіраційної бронхопневмонії у щурів.

Мета - створення ефективної та біологічно безпечної моделі гострої аспіраційної бронхопневмонії.

Матеріал та методи. При розробці методу за основу була взята класична модель відтворення гострої аспіраційної бронхопневмонії у щурів (Kubishkin \& Fomochkina, 2008). При виконанні роботи керувалися нормами та принципами Директиви 2010/63 СС з захисту тварин, Гельсінкської декларації (2008) та вимогами діючого законодавства України. Групі лабораторних щурів лінії Вістар масою 190220 г (20 особин) було проведене оперативне втручання з метою введення стороннього тіла у трахею. За допомогою провідника (ін'єкційна голка) стерильну капронову нитку довжиною 2,5 см та товщиною 0,2 мм вводили на глибину 2,5 см у трахею. Для цього тварину наркотизували тіопенталом (50 мг/кг), робили невеликий (до $1 \mathrm{~cm}$ ) розтин шкіри у проекції трахеї над грудиною по середній лінії, мобілізували трахею, проколювали iї провідником та вводили капронову нитку. Операційну рану ушивали. У контрольній групі (5 тварин) робили аналогічні маніпуляції за винятком введення капронової нитки у трахею. Розподіл тварин по групам здійснювали сліпим рандомізованим методом.

Експеримент виконували на базі кафедри патофізіології (зав. - проф. Панова Т.І.) та НДІ експериментальної та клінічної медицини НМУ імені О.О. Богомольця (директор проф. Натрус Л.В.). Тварин тримали на стандартному раціоні в умовах віварію НМУ імені О.О. Богомольця. Протягом одного місяця після операції визначали загальний стан тварин, ректальну температуру, ступень ціанозу, наявність задишки, частоту дихальних рухів (ЧДР), аускультативні прояви. На 7 та 21 
добу спостереження сліпим рандомізованим методом обирали по 5 тварин для виведення 3 експерименту під тіопенталовим наркозом. Розтинали грудну порожнину, легені відсепаровували, фотографували та зважували. Для проведення цитологічних досліджень робили відбиток з поверхні легень та отримували бронхо-альвеолярний змив шляхом багатократного їх промивання через трахею 10 мл фізіологічного розчину. Відбитки забарвлювали за Романовським-Гімзою. Світлову мікроскопію проводили на світлооптичному мікроскопі «Olimpus BX 40» додатково обладнаному цифровою камерою «Olimpus C3030-ADU» та програмним забезпеченням «Olimpus DP-Soft». У мазках крові виконували загальний аналіз з підрахунком кількості формених елементів.

Для статистичних досліджень використано програми MedStat i MedCalc v.15.1 (MedCalc Software bvba).

Результати. Під час операції, при введенні капронової нитки у трахею, у деяких тварин були відмічені хрипи, конвульсивні посмикування дихальних м'язів, експіраторна задишка. Ранній післяопераційний період протікав без особливостей, через 1-1,5 години щури відходили від наркозу, відновлювався грумінг, тварини починали споживати їжу та пити.

В першу добу у всіх тварин спостерігалися незначна задишка, поодинокі вологі хрипи, які було чутно на відстані, ректальна температура коливалась в межах $37,6-37,8^{\circ} \mathrm{C}$, ЧДР - 72-102 за хвилину. Всі тварини активно пересувались по клітці, проявляли реакції активного грумінгу, споживали корм та воду. В зоні післяопераційної рани відзначалися набряк та гіперемія. На другу добу у більшості тварин спостерігалися незначний ціаноз, задишка та утруднене дихання, поодинокі вологі хрипи; всі тварини були активні, ректальна температура коливалася у межах $37,4-38,0^{\circ} \mathrm{C}$.

На третю-четверту добу у тварин спостерігалися постійні виражені вологі хрипи, дихання часте (до 120 за хвилину) та поверхневе, температура коливалась в межах $37,2-38,4^{\circ} \mathrm{C}$; частота грумінгу знижувалася.

На п'яту добу у всіх тварин вислуховували виражені великопухирцеві хрипи, з'явилась крепітація. Дихання глибоке за участю додаткових дихальних м'язів. ЧДР в межах 90-102 на хвилину.

На шосту-сьому добу у тварин наростали явища ціанозу шкірних покривів та слизових оболонок, дихання утруднене з активним залученням додаткових дихальних м'язів, вислуховувалися хрипи, крепітація, була задишка. Температура тіла коливалась в межах $37,9-38,6^{\circ} \mathrm{C}$, що було на $1,0-1,5^{\circ} \mathrm{C}$ вище за початкові значення.

На другому-третьому тижнях зазначені зміни зберігалися, дихання було жорстким, утрудненим, вислуховувалися хрипи, крепітація, наявна задишка; у всіх тварин був виражений ціаноз. Така клінічна картина спостерігалася і на четвертому тижні спостереження. Крім того, звертали увагу наростаючі поведінкові розлади. Активність тварин була значно знижена, вони скупчувалися в одному кутку клітки, в'яло реагували на звукові та інші подразники.

Загалом, протягом спостереження відмічались зміни у поведінці щурів: збудження у перші дні змінювалося зниженням орієнтовно-рухової активності. Знижувався грумінг, щури менше слідкували за собою, хвости ставали темнішими (сірими), шерсть брудною. 3 другого-третього тижня щури ставали більш агресивними при безпосередньому контакті 3 дослідниками, що особливо було виражено через місяць спостереження.

За кількістю еритроцитів суттєвих зсувів визначено не було (табл. 1). За рівнем лейкоцитозу різниць по термінах дослідження також не виявлено. Натомість, кількість гранулоцитів у порівнянні з контролем зростала на 21 добу (у 1,4 рази; $р=0,007)$. Кількість лімфоцитів через 7 діб була значуще збільшена (у 1,3 рази; $p=0,048$ ) у порівнянні 3 контролем, а через 21 добу - зменшувалася та вже не відрізнялася від контрольного значення $(\mathrm{p}=0,48)$. У порівнянні з рівнем на 7 добу кількість лімфоцитів була меншою (у 1,4 рази; $\mathrm{p}=0,011)$. Ці зсуви ілюструвала величина гранулоцитарно-лімфоцитарного індексу (ГЛІ), яка у порівнянні з контролем через 7 діб була зменшеною (у 1,3 рази; $p=0,007)$, а через 21 добу - збільшеною (у 1,5 рази; $\mathrm{p}=0,003$ ). Це 
Таблиця 1. Кількість формених елементів у крові щурів

\begin{tabular}{|l|c|c|c|}
\hline \multirow{2}{*}{\multicolumn{1}{|c|}{ Показники }} & \multirow{2}{*}{ Контроль } & \multicolumn{2}{c|}{ Доба спостереження } \\
\cline { 3 - 4 } & & $\mathbf{7 - a}$ & $\mathbf{2 1 - a}$ \\
\hline Еритроцити, Т/л & $7,99 \pm 0,51$ & $8,30 \pm 0,72$ & $7,31 \pm 0,48$ \\
\hline Лейкоцити, Г/л & $9,25 \pm 0,74$ & $10,03 \pm 0,85$ & $9,56 \pm 0,62$ \\
\hline Гранулоцити, Г/л & $3,25 \pm 0,26$ & $3,08 \pm 0,27$ & $4,67 \pm 0,28^{*} \#$ \\
\hline Лімфоцити, Г/л & $4,25 \pm 0,32$ & $5,40 \pm 0,36^{*}$ & $3,96 \pm 0,22 \#$ \\
\hline ГЛІ, ум. од. & $0,72 \pm 0,04$ & $0,55 \pm 0,02^{*}$ & $1,11 \pm 0,08^{*} \#$ \\
\hline Тромбоцити, Г/л & $841,2 \pm 31,7$ & $776,7 \pm 40,4$ & $950,7 \pm 54,6 \#$ \\
\hline
\end{tabular}

Примітки: ГЛІ - гранулоцитарно-лімфоцитарний індекс; * - p<0,05 при порівнянні 3 контролем; $\#-$ p $<0,05$ при порівнянні з значеннями на 7-у добу.

узгоджувалося 3 даними про зсуви ГЛІ у при гострому легеневому запаленні i, у тому числі, при COVID (Huang et al., 2020).

Секційне дослідження показало, що через 7 діб легені були набряклими з блискучою поверхнею, блідо-рожевого кольору, мали нашарування фібрину, виражений ціаноз та, у більшості випадків-внутрішньотканинні геморагії (рис. 1). Через 21 добу ці зміни доповнювалися розвитком ателектазу та фіброзу (рис. 2).

Цитологічне дослідження на 7 день показало, що у відбитках з поверхні легень спостерігалося велике скупчення фібробластоїдних клітин з вираженими ознаками активації: клітини округлені, відростки цитоплазми широкі, ядра великі, ніжної структури, хоча ядерця не є видимими (рис. 3 а, б).

Зустрічалися поодинокі фібробласти 3 інтенсивно базофільною цитоплазмою (що вказувало на активний синтез білків). Поза скупчень $65-71 \%$ лімфоцитів, 9-15\% нейтрофілів, 20-25\% моноцитів 3 частковим диференціюванням в макрофаги. Мікроорганізми не знайдені. Епітеліальні клітини поодинокі, розрізнені. У бронхо-альвеолярному змиві відзначена невелика кількість клітин (див. рис. 3 в), багато кристалів солей. Присутні невеликі скупчення епітеліальних клітин з ознаками дистрофічних змін, напівзруйнованими ядрами в значній частині клітин. Клітинний склад: 51-56\% лімфоцитів, 25-29\% нейтрофілів, 11-15\% моноцитів. Зрілі макрофаги від-

Рис. 1. Секційне дослідження легенів щурів через 7 діб після моделювання аспіраційної пневмонії. Відмічено чисельні крововиливи (а), набряк, ціаноз (б), нашарування фібрину на поверхні (в).
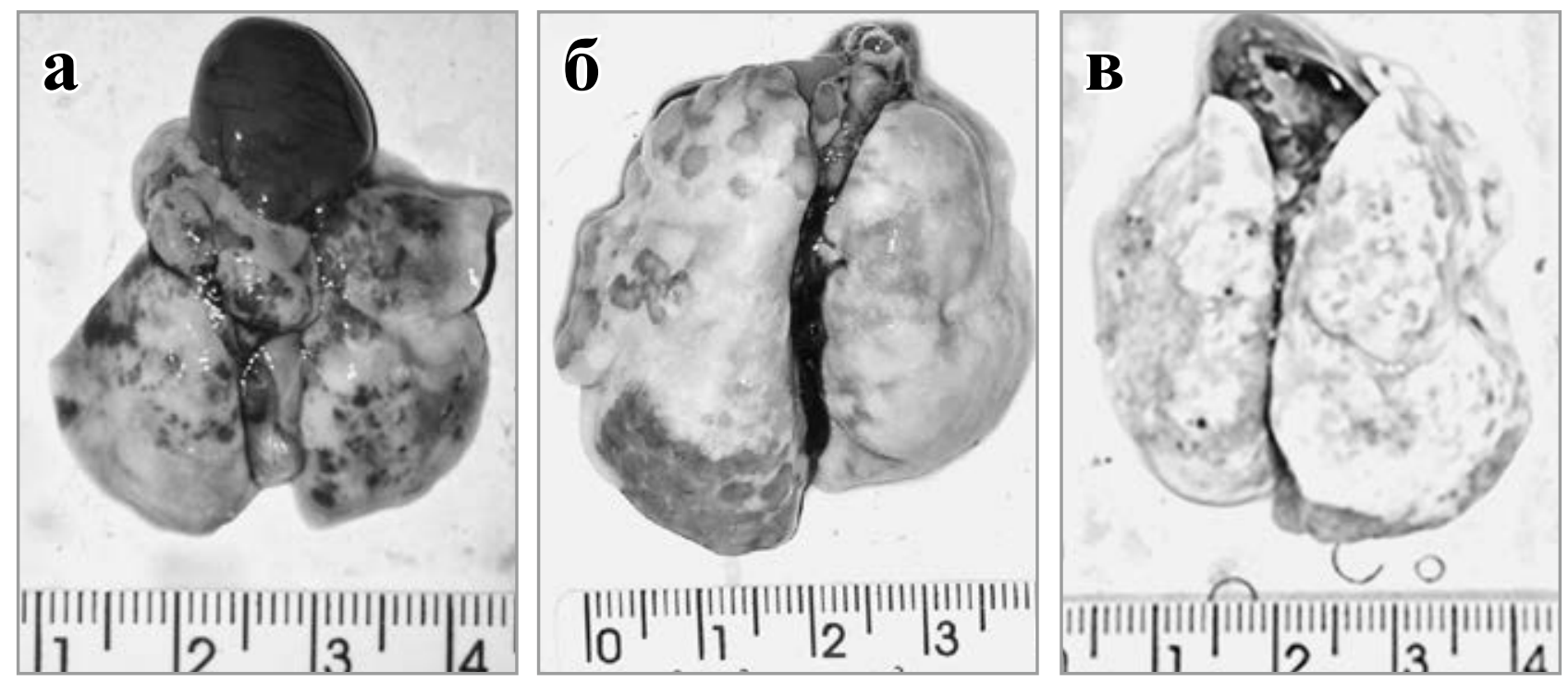

Ukrainian scientific medical youth journal, 2021, Issue 2 (124) http://mmj.nmuofficial.com 

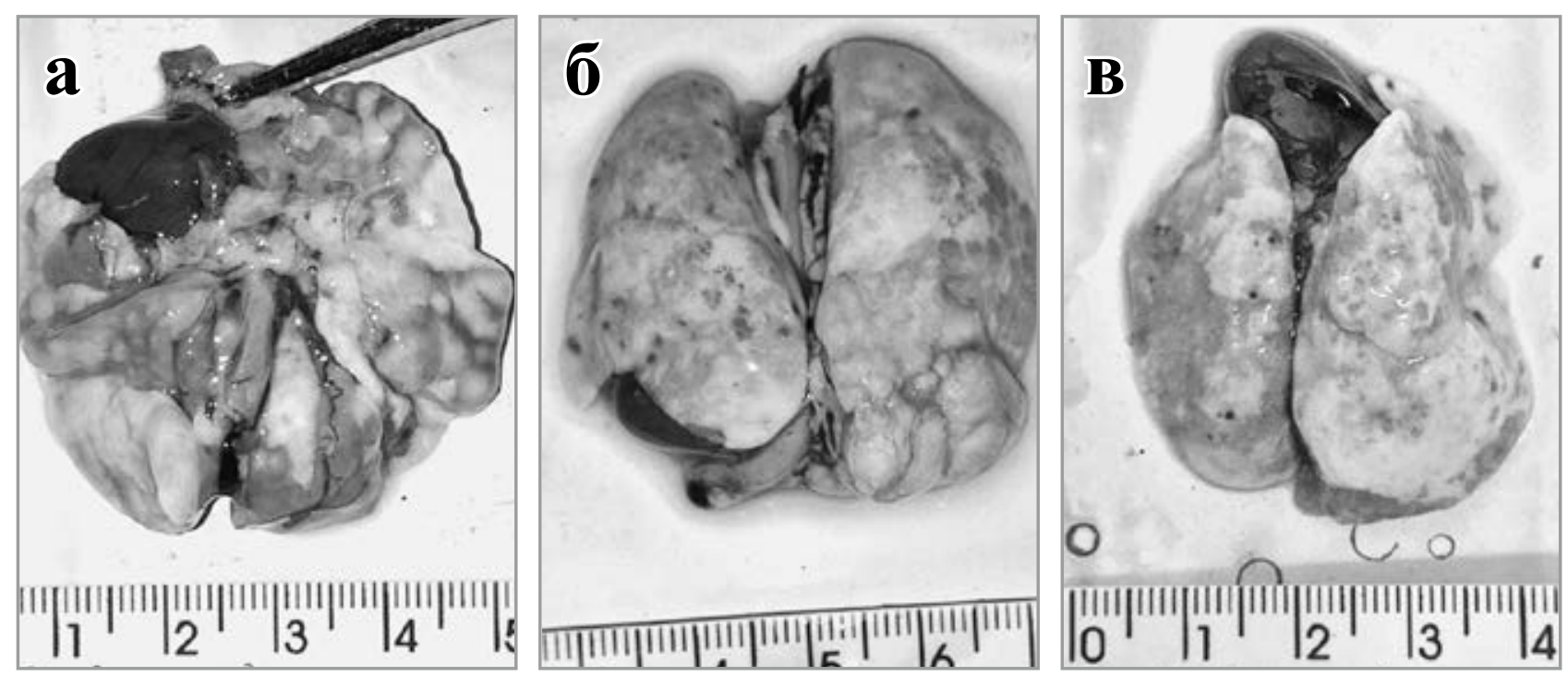

Рис. 2. Секційне дослідження легенів щурів через 21 добу після моделювання аспіраційної пневмонії. Відмічено ділянки ателектазу (а), набряк, ціаноз (б), фіброз (в).

сутні. Фібробласти поодинокі, незмінені. Мікроорганізмів не виявлено.

Через 21 добу в цитологічному мазку темних фібробластоїдних клітин у стані синтезу білка було набагато більше (рис. 4-a).

Інші клітини мали світлу цитоплазму з ознаками активації, широкими відростками та великими ядрами 3 ніжною структурою гетерохроматину. Спостерігалися ділянки лім- фоїдної інфільтрації, мікроорганізми не ідентифіковані. Епітеліальні клітини поодинокі, розрізнені з ознаками дистрофії.

Таким чином, цитологічне дослідження показало наявність проліферації фіброзної тканини та активацію біосинтетичних процесів у фібробластах, виражених дистрофічних змін бронхіального епітелію, лімфоїдної інфільтрації.

Рис. 3. Цитологічні відбитки з поверхні легень (a, б) та бронхо-альвеолярного змиву (в) через 7 діб після моделювання аспіраційної пневмонії. Фібробластоїдні клітини з вираженими ознаками активації та проліферації. Лімфоцитарна інфільтрація. Дистрофія бронхіального епітелію, лімфоїдна інфільтрація у мазках бронхо-альвеолярного змиву.

Забарвлення - за Романовським-Гімзою; $\times 1000$
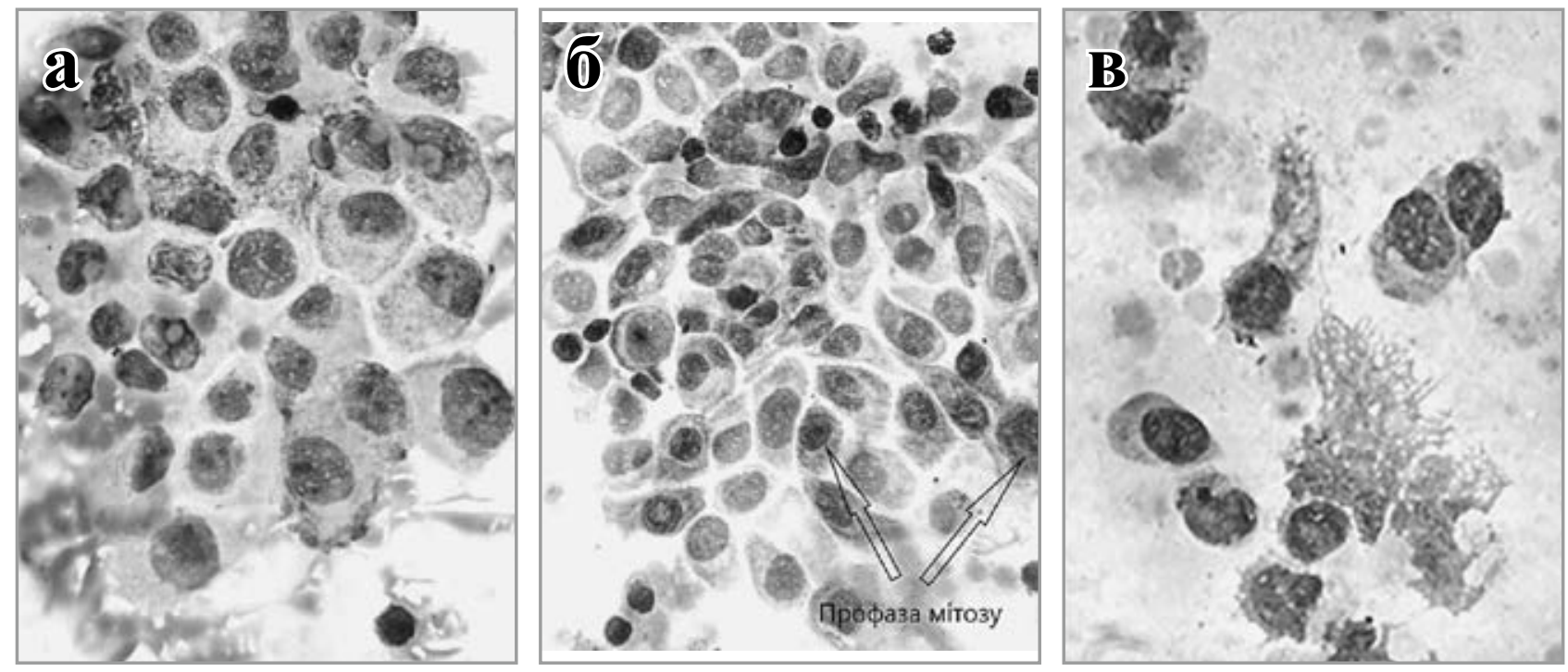

Ukrainian scientific medical youth journal, 2021, Issue 2 (124)

http://mmj.nmuofficial.com 

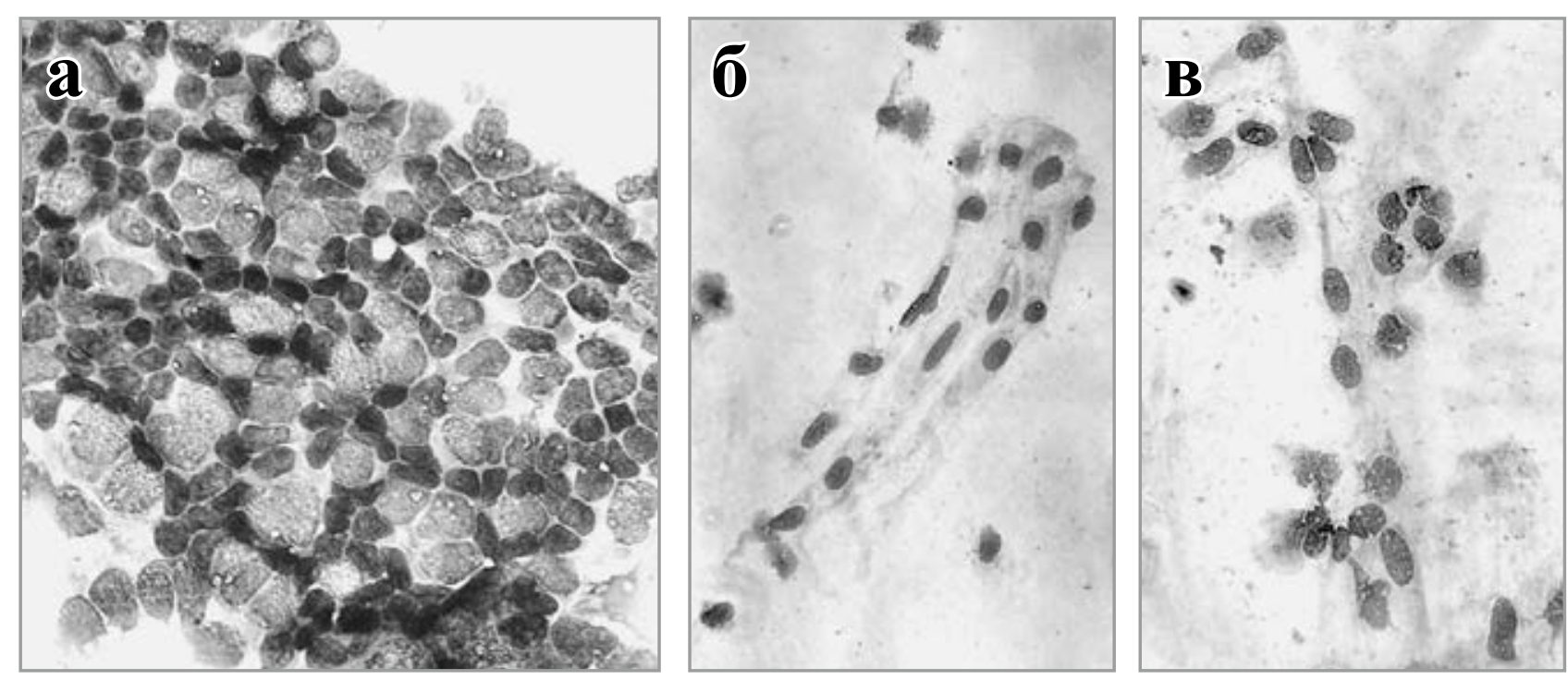

Рис. 4. Цитологічні відбитки з поверхні легень (а) та бронхо-альвеолярного змиву (б, в) через 21 добу після моделювання аспіраційної пневмонії. Фібробластоїдні клітини з ознаками активного синтезу білка. Лімфоцитарна інфільтрація. Дистрофія бронхіального епітелію.

Забарвлення - за Романовським-Гімзою; $\times 1000$

Обговорення. За даними патоморфологічного дослідження у пацієнтів, які померли від дихальної недостатності, пов язаної з COVID-19, гістологічно було показане дифузне альвеолярне пошкодження з периваскулярною інфільтрацією Т-лімфоцитів (Ackermann et al., 2020). У пацієнтів з легким перебігом захворювання були визначені: важке ендотеліальне ушкодження, внутрішньоклітинна присутність вірусу, пошкодження клітинних мембран. У наших дослідженнях цитологічно показано наявність дистрофічних змін альвеолярного епітелію, що доводить залучення пошкодження пневмоцитів при даній моделі, а також - активна лімфоїдна інфільтрація.

Показано, що активація альвеолярних макрофагів і епітеліальних клітин легенів викликає виділення прозапальних цитокінів інтерлейкіну-1 $(\mathrm{IL}-1 \beta$ ) та інтерлейкіну-6 (IL$6)$, а також фактору некрозу пухлин- $\alpha$ (TNF $\alpha$ ), збільшує експресію молекул клітинної адгезії (CAM) і васкулоендотеліального фактору росту (VEGF), що збільшує проникність ендотелію і знижує барґєрний захист (Kempuraj et al., 2020; Polidoro, Hagan, de Santis Santiago, \& Schmidt, 2020). Це сприяє поширенню вірусу, а з іншого боку - посилює інфільтрацію нейтрофілів і активованих моноцитів. Такі мо- лекулярні механізми обумовлюють розвиток ГРДС. Одночасно, гострофазові запальні реакції на тлі дисбалансу ренін-ангіотензин-калікреїн-кінінової системи (РАККС) активують тромбоцити, утворення фібриногену та інших протромботичних факторів, що сприяє поширеному тромбуванню 3 розвитком мікроангіопатії. Поєднання гострого запального пошкодження легенів на тлі дисбалансу РАККС та тромбофілії складає патофізіологічну основу формування «подвійного удару» («dual hit» injury) - COVID-асоційованої легеневої травми (CALI) (Polidoro et al., 2020; Alharthy, Faqihi, Memish, \& Karakitsos, 2020). ). Це диктує необхідність в експерименті нашарування на гостре запальне пошкодження, динаміка якого моделюються за застосованою у нашому дослідженні методикою, одночасного впливу, що може підвищувати активацію макрофагів 3 метою посилення запалення та моделювання ГРДС. Прикладом такого впливу може бути моделювання пірогеналової асептичної лихоманки (Rogovyy, Kopchuk, Filipova, \& Dical, 2014).

Можливі напрямки експериментальної терапії, що можуть бути запропоновані, виходячи 3 уявлення теорії «подвійного удару», включають препарати, що здатні зменшити за- 
палення, набряк і активацію імунних клітин, а також лікування інтерфероном, кортикостероїдами, моноклональними антитілами до прозапальних факторів (наприклад, тоцілізумаб) (Gallelli, Zhang, Wang, \& Fu, 2020).

COVID-19-асоційоване пошкодження дихальної системи відрізняється великою різноманітністю, починаючи від легких симптомів верхніх дихальних шляхів і закінчуючи важким ГРДС з розвитком фіброзу легенів. При цьому роль антифібротичної терапії у пацієнтів з наслідками фіброзу після ГРДС визначена недостатньо, тоді як антифібротична терапія може потенційно лікувати важкий COVID-19 і відігравати роль у профілактиці фіброзу після ГРДС (George, Wells, \& Jenkins, 2020). Наші дослідження показали як клінічно, так i об'єктивно - за секційними та цитологічними результатами, розвиток вираженого фіброзу легень, орієнтовно з початком на другий тиждень післяопераційного періоду.

Хоча легеневий фіброз може виникнути i за відсутності чітко вираженого збудливого агенту та без клінічно чітко вираженої початкової гострої запальної фази, він частіше асоціюється з важкою травмою легенів (Ojo, Balogun, Williams, \& Ojo, 2020). Це може бути пов'язано з респіраторними інфекціями, хронічними гранулематозними захворюваннями, ліками та порушеннями сполучної тканини. Клінічні, рентгенологічні та аутопсійні дані вказують на те, що фіброз легенів є центральним патологічним станом при розвитку ГРДС. Предикторами легеневого фіброзу при COVID-19 є похилий вік, тяжкість захворювання, тривалість перебування в реанімації та штучної вентиляції легень, куріння та хронічний алкоголізм. Відсутність доведеної ефективної цілеспрямованої антифібротичної терапії диктує необхідність активного експериментального вивчення цього питання.

Висновок. Таким чином, модель гострої аспіраційної бронхопневмонії у щурів дозволяє отримати основні клінічні та морфологічні прояви гострого пошкодження легень 3 наявністю ціанозу, задишки, вологих хрипів та крепітації, а у легенях - набряку, крововиливів, активного фіброзування, лімфоїдної інфільтрації.

Перспективи подальших досліджень. Отримані результати вказують на можливість використання моделі гострої аспіраційної бронхопневмонії для відтворення основних ланок патогенезу COVID-асоційованого пошкодження легень, але й показують необхідність подальшого проведення поглибленого морфологічного дослідження, а також вивчення можливостей додаткового моделювання елементів гіперімунного запалення.

Авторські внески. Концепція - 3С, Курація даних - 3С, Формальний аналіз - ПП, ЛМ Придбання фінансування - Дослідження - ПП, ЛМ, МД Методологія - ЗС, ПП Адміністрація проекту - ЗС, ПП Ресурси - ЗС Програмне забезпечення - Нагляд - ЗС Перевірка - 3С, ЛМ Візуалізація - ПП, ЛМ Письмово-оригінальний проект підготовки - ЛМ, ЗС Огляд та редагування - 3С

Інформація про конфлікт інтересів. Автори заявляють про відсутність будь-якого конфлікту інтересів і власної фінансової зацікавленості при підготовці цієї статті.

Дане дослідження не отримало зовнішнього фінансування.

\section{ЛІТЕРАТУРА}

Ackermann, M., Verleden, S. E., Kuehnel, M., Haverich, A., Welte, T., Laenger, F., Vanstapel, A., Werlein, C., Stark, H., Tzankov, A., Li, W. W., Li, V. W., Mentzer, S. J., \& Jonigk, D. (2020). Pulmonary Vascular Endothelialitis, Thrombosis, and Angiogenesis in Covid-19. The New England journal of medicine, 383(2), 120-128. https://doi. org/10.1056/NEJMoa2015432

Alharthy, A., Faqihi, F., Memish, Z. A., \& Karakitsos, D. (2020). Lung Injury in COVID-19-An Emerging Hypothesis. ACS chemical neuroscience, 11(15), 2156-2158. https://doi.org/10.1021/acschemneuro.0c00422.

Boudewijns, R., Thibaut, H.J., Kaptein, S.J.F. et al. STAT2 signaling restricts viral dissemination but drives severe pneumonia in SARS-CoV-2 infected hamsters. Nat Commun 11, 5838 (2020). https://doi.org/10.1038/s41467-02019684-y 
Cai, A., McClafferty, B., Benson, J., Ramgobin, D., Kalayanamitra, R., Shahid, Z., Groff, A., Aggarwal, C. S., Patel, R., Polimera, H., Vunnam, R., Golamari, R., Sahu, N., Bhatt, D., \& Jain, R. (2020). COVID-19: Catastrophic Cause of Acute Lung Injury. South Dakota medicine : the journal of the South Dakota State Medical Association, 73(6), $252-260$.

Chung, M., Bernheim, A., Mei, X., Zhang, N., Huang, M., Zeng, X., Cui, J., Xu, W., Yang, Y., Fayad, Z. A., Jacobi,A., Li, K., Li, S., \& Shan, H. (2020). CT Imaging Features of 2019 Novel Coronavirus (2019-nCoV). Radiology, 295(1), 202-207. https://doi.org/10.1148/radiol.2020200230

COVID-19. (2021). Dashboard by the Center for Systems Science and Engineering (CSSE) at Johns Hopkins University.

Franks, T. J., Chong, P. Y., Chui, P., Galvin, J. R., Lourens, R. M., Reid, A. H., Selbs, E., McEvoy, C. P., Hayden, C. D., Fukuoka, J., Taubenberger, J. K., \& Travis, W. D. (2003). Lung pathology of severe acute respiratory syndrome (SARS): a study of 8 autopsy cases from Singapore. Human pathology, 34(8), 743-748. https://doi.org/10.1016/s00468177(03)00367-8

Gallelli, L., Zhang, L., Wang, T., \& Fu, F. (2020). Severe Acute Lung Injury Related to COVID-19 Infection: A Review and the Possible Role for Escin. Journal of clinical pharmacology, 60(7), 815-825. https://doi.org/10.1002/jcph.1644

George, P. M., Wells, A. U., \& Jenkins, R. G. (2020). Pulmonary fibrosis and COVID-19: the potential role for antifibrotic therapy. The Lancet. Respiratory medicine, 8(8), 807-815. https://doi.org/10.1016/S2213-2600(20)30225-3

Golden, J. W., Cline, C. R., Zeng, X., Garrison, A. R., Carey, B. D., Mucker, E. M., White, L. E., Shamblin, J.D., Brocato, R. L., Liu, J., Babka, A. M., Rauch, H. B., Smith, J. M., Hollidge, B. S., Fitzpatrick, C., Badger, C. V., \& Hooper, J.W. (2020). Human angiotensin-converting enzyme 2 transgenic mice infected with SARS-CoV-2 develop severe and fatal respiratory disease. JCI insight, 5(19), e142032. https://doi.org/10.1172/jci.insight.142032

Huang, C., Wang, Y., Li, X., Ren, L., Zhao, J., Hu, Y., Zhang, L., Fan, G., Xu, J., Gu, X., Cheng, Z., Yu, T., Xia, J., Wei, Y., Wu, W., Xie, X., Yin, W., Li, H., Liu, M., Xiao, Y., .. Cao, B. (2020). Clinical features of patients infected with 2019 novel coronavirus in Wuhan, China. Lancet (London, England), 395(10223), 497-506. https://doi.org/10.1016/ S0140-6736(20)30183-5

Kempuraj, D., Selvakumar, G. P., Ahmed, M. E., Raikwar, S. P., Thangavel, R., Khan, A., Zaheer, S. A., Iyer, S. S., Burton, C., James, D., \& Zaheer, A. (2020). COVID-19, Mast Cells, Cytokine Storm, Psychological Stress, and Neuroinflammation. The Neuroscientist : a Review Journal Bringing Neurobiology, Neurology and Psychiatry, 26(5-6), 402-414. https://doi.org/10.1177/1073858420941476

Kubyshkin, A. V., \& Fomochkina, I. I. (2008). Ukrains $>$ kyi biokhimichnyi zhurnal (1999), 80(1), 89-95.

Leist, S. R., Dinnon, K. H., 3rd, Schäfer, A., Tse, L. V., Okuda, K., Hou, Y. J., West, A., Edwards, C. E., Sanders, W., Fritch, E. J., Gully, K. L., Scobey, T., Brown, A. J., Sheahan, T. P., Moorman, N. J., Boucher, R. C., Gralinski, L. E., Montgomery, S. A., \& Baric, R. S. (2020). A Mouse-Adapted SARS-CoV-2 Induces Acute Lung Injury and Mortality in Standard Laboratory Mice. Cell, 183(4), 1070-1085.e12. https://doi.org/10.1016/j.cell.2020.09.050

Lu, R., Zhao, X., Li, J., Niu, P., Yang, B., Wu, H., Wang, W., Song, H., Huang, B., Zhu, N., Bi, Y., Ma, X., Zhan, F., Wang, L., Hu, T., Zhou, H., Hu, Z., Zhou, W., Zhao, L., Chen, J., ... Tan, W. (2020). Genomic characterisation and epidemiology of 2019 novel coronavirus: implications for virus origins and receptor binding. Lancet (London, England), 395(10224), 565-574. https://doi.org/10.1016/S0140-6736(20)30251-8.

Ojo, A. S., Balogun, S. A., Williams, O. T., \& Ojo, O. S. (2020). Pulmonary Fibrosis in COVID-19 Survivors: Predictive Factors and Risk Reduction Strategies. Pulmonary medicine, 2020, 6175964. https://doi.org/10.1155/2020/6175964

Polidoro, R. B., Hagan, R. S., de Santis Santiago, R., \& Schmidt, N. W. (2020). Overview: Systemic Inflammatory Response Derived From Lung Injury Caused by SARS-CoV-2 Infection Explains Severe Outcomes in COVID-19. Frontiers in immunology, 11, 1626. https://doi.org/10.3389/fimmu.2020.01626

Qu, L., Li, J., \& Ren, H. (2020). COVID-19: the epidemiology and treatment. British journal of hospital medicine (London, England : 2005), 81(10), 1-9. https://doi.org/10.12968/hmed.2020.0580

Rogovyy, Yu. E., Kopchuk, T. G., Filipova, L. O., \& Dical, M. V. (2014). [The pathogenesis of disorders of the functional-biochemical state of the kidneys in the development of aseptic fever]. Modern problems of science and education, (2), 380-380.

Suster, S., Moran, A.C. (2013) Biopsy interpretation of the lung. 1st ed. Lippincott Williams \& Wilkins, Wolters Kluwer.

Wang, D., Hu, B., Hu, C., Zhu, F., Liu, X., Zhang, J., Wang, B., Xiang, H., Cheng, Z., Xiong, Y., Zhao, Y., Li, Y., Wang, X., \& Peng, Z. (2020). Clinical Characteristics of 138 Hospitalized Patients With 2019 Novel Coronavirus-Infected Pneumonia in Wuhan, China. JAMA, 323(11), 1061-1069. https://doi.org/10.1001/jama.2020.1585

World Health Organization. (2020). World Health Organization coronavirus disease (COVID-19) dashboard. 


\section{МОДЕЛИРОВАНИЕ ОСТРОЙ АСПИРАЦИОННОЙ БРОНХОПНЕВМОНИИ}

\author{
Пенский Павел ${ }^{1}$, Литвинец Михаил ${ }^{2}$, \\ Мусиенко Дарья ${ }^{1}$, Зяблицев Сергей ${ }^{3}$ \\ ${ }^{1}$ Студентка медицинского факультета №4 \\ НМУ имени А.А. Богомольца, г. Киев, \\ Украина \\ ${ }^{2}$ Студент медицинского факультета № 2 \\ НМУ имени А.А. Богомольца, г. Киев, \\ Украина \\ ${ }^{3}$ Кафедра патофизиологии НМУ имени \\ А.А. Богомольца, г. Киев, Украина
}

Аннотация. В настоящее время существует потребность в создании доступной экспериментальной модели для воспроизведения основных патогенетических механизмов COVID-ассоциированного повреждения легких. Первым этапом такой модели может быть воспроизведения острой аспирационной бронхопневмонии у крыс. Цель - создание эффективной и биологически безопасной модели острой аспирационной бронхопневмонии. Методы. Группе лабораторных крыс линии Вистар (n=20) с соблюдением биоэтических норм под тиопенталовым обезболиванием было проведено оперативное вмешательство с введением в трахею стерильной капроновой нити длиной 2,5 см и толщиной 0,2 мм на глубину 2,5 см. В контрольную группу вошло 5 животных. На 7 и 21 день животных выводили из эксперимента, проводили патоморфологические, цитологических и гематологические исследования. Для статистических исследований использованы программу MedStat (США). Результаты. В течение наблюдения у животных нарастали явления цианоза кожных покровов и слизистых оболочек, дыхание затруднялось с активным привлечением дыхательных мышц, выслушивались выражены хрипы, крепитация. Ректальная температура увеличивалась на 1-1,5ㄷ. На 21-й день увеличивался гранулоцитарно- лимфоцитарный индекс (в 1,5 раза; $p=0,003)$. На секции через 7 дней легкие были набухшими, бледно-розового цвета, имели наслоения фибрина, выра-

\section{MODELING \\ OF ACUTE ASPIRATION \\ BRONCHOPNEUMONIA}

\section{Pensky Paul ${ }^{1}$, Lytvynets Mykhailo², Musienko Daria ${ }^{1}$, Zyablitsev Sergey ${ }^{3}$}

${ }^{1}$ A student of the medical faculty №4 NMU named after OO Bogomolets, Kyiv, Ukraine

${ }^{2}$ Student of the Medical Faculty № 2 NMU named after OO Bogomolets, Kyiv, Ukraine

${ }^{3}$ Department of Pathophysiology of NMU named after OO Bogomolets, Kyiv, Ukraine

Abstract. There is currently an urgent need to create an available experimental model to reproduce the main pathogenetic mechanisms of COVID-associated lung injury. The first stage of such a model may be the reproduction of acute aspiration bronchopneumonia in rats. Aim - to establish an effective and biologically safe model of acute aspiration bronchopneumonia. Methods. A group of laboratory Wistar rats $(n=20)$ with full observance of bioethical norms under thiopental anesthesia underwent surgery with the introduction into the trachea of sterile nylon thread 2.5 $\mathrm{cm}$ long and $0.2 \mathrm{~mm}$ thick to a depth of $2.5 \mathrm{~cm}$; in the control group included 5 animals. On days 7 and 21, the animals were removed from the experiment, made pathomorphological, cytological and hematological studies. The MedStat program (USA) was used for statistical surveys. Results. During the observation, the animals developed cyanosis of the skin and mucous surfaces, breathing became difficult with the active involvement of the respiratory muscles, severe rales and crepitation were heard. Rectal temperature increased by $1-1.5^{\circ} \mathrm{C}$. On the $21 \mathrm{st}$ day, the granulocyte-lymphocyte index increased ( 1.5 times; $\mathrm{p}=0.003$ ). On sectional examination after 7 days, the lungs were swollen, pale pink in color, had layers of fibrin, severe cyanosis, intra-tissue hemorrhage. After 21 days, these changes were supplemented by the development of atelectasis and fibrosis. Cytological examination showed proliferation of fibrous tissue with activation of biosynthetic processes, severe dystrophy of the bronchial epithelium, lymphoid infiltration. Conclusion. The model of acute aspiration bronchopneumonia in 
женный цианоз, внутритканевые геморрагии. Через 21 день эти изменения дополнялись развитием ателектаза и фиброза. Цитологическое исследование показало пролиферацию фиброзной ткани с активацией биосинтететичних процессов, выраженную дистрофию бронхиального эпителия, лимфоидную инфильтрацию. Выводы. Модель острой аспирационной бронхопневмонии у крыс позволяет получить основные клинические и морфологические проявления острого повреждения легких с наличием цианоза, одышки, влажных хрипов и крепитации, а в легких - отека, кровоизлияний, активного фиброзирования.

Ключевые слова: аспирационные острая бронхопневмония, эксперимент, острый респираторный дистресс-синдром, фиброз. rats allows to obtain the main clinical and morphological manifestations of acute lung damage with cyanosis, shortness of breath, wet wheezing and crepitation, and in the lungs - edema, hemorrhage, active fibrosis.

Key words: aspiration acute bronchopneumonia, experiment, acute respiratory distress syndrome, fibrosis. 